\title{
The Casual Relationship Between Debt and Profitability: The Case of Italy
}

\author{
By Marco Muscettola* \\ Francesco Naccarato ${ }^{\dagger}$
}

\begin{abstract}
This paper examines the impact of debt on corporate profitability using a longitudinal sample of 7,370 Italian SMEs operating in the commerce sector during 2006-2010. Being based on the simple moving-average analysis of the profitability ratios, as a result of debt changes, econometric evidence supports the hypothesis that there is a non-monotonic relationship between debt and profitability. However, if the nonmonotonic correlation is ignored, the debt-profitability relationship is likely to be negative in some areas of Italy. Otherwise, in regions where the demand for bank credit is higher (or the bank supply is lower), the negative correlation is muffled by a reverse effect: less financial resources make the evaluation of credit-worthiness more selective. Consequently, highly levered firms are considered to be those that have primarily higher profitability, and, then, the best rating.
\end{abstract}

Keywords: Corporate profitability, Correlation matrix, Credit market, Indebtedness.

\section{Introduction}

According to the agency costs theory, there are two contradictory effects of debt on profitability while capital structure ineluctably depends on variables, specified exogenously on the grounds of the bank credit market. Evidently, the Italian credit market is, in its own turn, strongly affected by external factors. Especially during this period of economic downturn (Muscettola 2014c), Italian firms do not renounce bank loans although they have an adequate selffinancing ${ }^{1}$.

In simple words, a comprehensive theory covering all the aspects of indebtedness does not exist, as the manifold nature of this matter inevitably leads to a partial and systemic argumentation. A few business theories have, recently, been developed along with the analysis of risks associated to indebtedness. The effects of "value creation" have also been under study on the basis of the "contingent claim analysis". In this context, the bank debt is considered to be capable of either creating or destroying wealth.

The developments in the economic theory were followed by qualitatively new theories on business economics, according to which a firm's indebtedness choice, besides being a significant decision, also enhances its chance to support

\footnotetext{
${ }^{*}$ Independent Researcher, Italy.

${ }^{\dagger}$ Researcher/Adjunct Professor, University of Padova, Italy.

${ }^{1}$ This thesis is supported by several papers that have examined the credit market in Italy as Di Giulio (2009), Albertazzi and Marchetti (2010), De Socio (2010), Accetturo et al. (2011), Bonaccorsi and Sette (2012), Muscettola (2015c).
} 
previous investments on the side of its regular performance, in the case where the profitability of loans is higher than the costs of financing. In this sense, some aspects of profitability, associated to development and wealth, could be compatible to holding a debt. On the other hand, indebtedness has a negative impact on the firm's vulnerability, due to major financial exposure. Moreover, the main factors that bias a firm's leverage are, also, influenced by elements exogenous to the firm per se, meaning that indebtedness choices are a quite complicated issue.

If average leverage is regarded as a consequence of the credit market, more notes must be added concerning the bank's resource allocation, that usually do not hit the mark targeted as investing. In fact, the majority of banks do not carry out more than a static type analysis, featuring the counterparty rating combined with a transactional phase ${ }^{1}$.

Even though only incidentally taking under consideration entrepreneurs' plans as well as business strategic plans and consistent qualitative variables, banks award firms a static judgement regarding their insolvency chances based on statistical scoring methods. This does not mean that the rating models used by banks do not work fine, but only that the instruments of statistical analysis are usually used in a rigid and critical way (Muscettola 2015b).

In the present study, we assume that the rate of corporate profitability depends on the dynamics of capital structure and vice versa. Firms that are able to finance themselves based on their own profits require external capital at a lesser degree. Alternatively, the hypothesis can be explained as follows: "if the firm's profitability grows, financial indebtedness should be reduced". These aspects need to be transposed into specific territorial frames, where the influence of other variants and the level to which they affect the corporate leverage of Italian firms, needs to be taken under consideration.

The present essay consists of six parts, including this introduction. The next two sections illustrate major academic studies, which focus on the relationship between corporate profitability and indebtedness, and discuss the advantages and the limitations of the specific sample we used, while it also describes the characteristics of the input data and provides the definition of the variables related to the study, respectively. Subsequently, there is a descriptive analysis of our sample in relation with the chosen indicators presented. This section also features a correlation matrix as well as graphic evidence of moving averages. In the semi-final section the analysis is extended by dividing the sample in ten territorial zones. Finally, the last section presents the conclusions.

\footnotetext{
${ }^{1}$ The use of "rating" instrument in banking strictly depends on two orders of primary causes (Muscettola and Gallo 2008). The first is about the bank organizational structure for preliminary credit, with accurate internal rules and related-risk acceptance grids as set by the risk management office. The second cause is the bank interest in the accounting calculation of expected, and unexpected, loss of credit to disburse, so that the bank may exactly insert it into its own credits portfolio, with a due weight in terms of risk, according to domestic and international laws. This way the models can be backward-looking, based on historical and elapsed data, rather than pretty synonymous of a business future potentiality.
} 


\section{Literature Review}

Recently, the corporate indebtedness and profitability have been in the center of academic attention. Some studies show a positive relationship between leverage and profitability, others show a negative one and, others, finally, show an absence of a specific causal relationship between the two dimensions (Muscettola 2014a). Furthermore, the debate among the three doctrines occurs not only empirically but also theoretically.

Regardless of the results obtained, in all the studies the general trend that emerges is that the formation of preferences of corporate managers regarding either debt finance or equity finance is based on the pursuit of maximum profits. Apparently, profit maximization induces important alterations in the firm's debt and equity finance intersecting with six theories which highlight the influence of debt on corporate profitability; namely, the signalling theory, asymmetric information theory, market timing theory, tax theory, bankruptcy cost and the agency costs theory. Prior to these theories, the company's strategy choices was decided and planned on the basis of the known theories of capital structure: the pecking order theory ${ }^{1}$ and Static trade-off theory ${ }^{2}$. The signalling theory, asymmetric information and market timing theory are included in the pecking order framework, while the tax theory, bankruptcy cost and agency cost are incorporated in the static trade-off theory.

Most of the empirical research conducted shows a negative relationship between profitability and debt. The related papers, consistent with the pecking order theory, are the ones of Kester (1986), where a notably negative relationship between profitability and debt ratios in American and Japanese manufacturing firms was found; Titman and Wessels (1988), who demonstrated that firms with high profit levels would preserve moderately lower debt intensities; Rajan and Zingales (1995), who also found a significantly inverse relationship between profitability and leverage in their sample of firms; Fama and French (1998), who revealed that debt handling does not necessarily confer tax benefits, as highly indebted firms may actually cause agency problems among shareholders and managers or creditors, reflecting a negative connection between debt and profitability; Cassar and Holmes (2003) who studied debt's impact on the capital structure of SME's in Australia and, like Hall et al. (2004), found an inverse relationship between profitability and debt ratios; Graham (2004), who showed a negative connection between total debt and profitability, especially for firms that are big and profitable; Abor (2005) who found an inverse relationship between profitability of listed firms in Ghana and long-term indebtedness; Amidu (2007) who studied the factors of capital structure of banks in Ghana and

\footnotetext{
${ }^{1}$ The theory is based on the eradication of the hypothesis of perfect information, and the business management, since recognizes the true value of its assets, matures that is cheaper to finance its investments by self-financing, first, and then via debt. Firms will only appeal to the risk capital as extrema ratio.

2 The theory affirms that firms are steered, to seek their own optimal capital structure per each single type of business, based on quantification of costs, and benefits of debt. Firms choose their financial configuration, offsetting the benefits of debt to the costs of instability.
} 
established an opposite correlation between short-term debt and firm productivity.

As opposed to the above findings, some researchers have found a positive association between leverage and firm profitability. The existence of a positive connection between profitability and firm leverage is supported in the studies of Leibestein (1966), Nerlove (1968), Baker (1973), Taub (1975) through a regression analysis, Peterson and Rajan (1994), Roden and Lewellen (1995) in a study about leverage buyout of firms, Champion (1999) and Abor (2008), analysing only short-term debt.

The review of the empirical literature pertaining to the impact of debt on profitability leads to the following ascertainment: first, most of the practical studies focus on listed companies or big firms and second, there are only a few studies on the case of the Italian firms. It is our aspiration that this study fills this gap, by contributing to the existing empirical literature on the relationship between debt and profitability of the Italian SMEs with a large sample of commercial firms grouped according to their territorial headquarters.

\section{Data Description and Variables}

Our main objective is to investigate whether corporate leverage has been diminishing profitability during the recent years and if it is possible to establish a link between debt and profitability as well as the type of this relationship. There are several techniques to measure debt and profitability. According to the prevalent trends in the literature and in order to be able to compare our results to the findings of other studies, we adopt the six measures of profitability ${ }^{1}$ and three measures of debt $^{2}$ most commonly used. It is also worth to note that each of the variables used to create the ratios was found to comply with the principles of monotonicity and passed all the sensitivity and specificity tests (Roc curve).

There are three measures of indebtedness: financial debts on total assets (FDA), debt ratio (DR) and total debt on equity (DOE). Regarding profitability, there are six valid measures: return on equity (ROE), return on sales (ROS),operating profit on total debt (OPD), EBITDA on investment (EOI), return on investment (ROI) and return on assets (ROA).

\footnotetext{
${ }^{1}$ According to Saleem and Rehman (2011), net income or profit after tax to equity is return on equity (ROE) ratio, whereas, operating profit to total assets and operating profit to capital employed are ROA and ROI ratios respectively (Muscettola 2014d). According to Muscettola and Pietrovito (2012) operating profit to sales is return on sales (ROS). And according to Muscettola and Naccarato (2013) operating profit to sales and Ebitda to total debt are EOI and OPD respectively.

${ }^{2}$ According to Hovakimian et al. (2001), as regards to total debts to total assets is called debt to assets or simply debt ratio (DR). Whereas, long term debts to an equity is called debt to equity (DOE) ratio. According to Muscettola (2013) as regard to financial debts ratio (FDA).
} 
The source for empirical data is the yearly statements provided by Four Finance $^{1}$. The sampling frame consists of the 7,370 active private companies operating exclusively in commercial sectors. The firms analysed are small and medium-sized enterprises (SMEs) with revenues from 5 million to 50 million euros, operating in Italy. The reference year for the analysis is 2009. All the firms which have been insolvent at least until the year 2010 are excluded. A firm is considered as a default-grade if existence of credit overdue for more than three months ${ }^{2}$ is reported in the Central Credit Register. The selection of commercial firms is made in such a way that would enable us to create a sample homogeneous in the size and type of the company. The sample's homogeneity as well as the non-excessive series of variables linkable to the firms' data allows for the extension of our findings to other firms, providing external validity, the normalization of the trends found and, lastly, for more effective management of the outliers of the examined sample.

In addition, we eliminate firm-years for which the value of capital stock is less than four million euros and those exhibiting real assets, total assets, debt, firm's earnings or sales growing faster than usual or in sharp decline. We also eliminate firms with negative net worth and earnings, operating profit or being Ebitda negative $^{3}$. Outliers are removed in order to avoid extreme values that could cause unbalance in the average values and distribution of the variables. We also delete the observations which are situated outside the interval defined by the 2 nd and the 98th percentile. In this way, we avoid heteroskedasticity problems (Muscettola 2014b).

The final sample, for which complete financial information is available for the entire span of the five years, from 2006 to 2010, is based on annually collected data, with the base year being $2009^{4}$.

The study is divided in two parts. The first part is devoted to trend analysis of indebtedness measures and profitability ratios. In the second one, the correlation results for all variables, calculated both at the whole sample and at the geographical subsamples, created on the basis of bank supply credit, are presented.

In Table 1, the summary statistics are reported. The distribution of the average and median values, the standard deviation as well as the first and third quartile for each ratio of the explanatory variables are also presented.

\footnotetext{
${ }^{1}$ The authors wish to thank Four Finance Sas for making available the test sample and for having assembled the financial statements analyzed. FourFinance assembled and reclassified financial statements collected from multiple databases as, above all, Cerved Group Spa. As for the creation of the statistical model, the preliminary operations on the data, the choice of the outliers and the creation of financial ratios, the reader ought to refer exclusively to the authors.

${ }^{2}$ This classification is narrower than the one usually applied in bank rating models, as these consider default to be the onset of severe financial suffering which borrowers cannot resolve if unaided, and through which the credit and loans settled may be lost.

${ }^{3}$ In this way the distribution of the selected indexes answer positively to the principles of monotonicity.

${ }^{4}$ We preferred year 2009 because it was the period with the most available data and with a lower standard deviation between the variables.
} 
Table 1. Summary Statistics of Accounting Ratios Used in the Research, 2009

\begin{tabular}{|l|l|c|c|c|c|c|}
\hline \multicolumn{2}{|c|}{ Accounting Ratio } & Quartile 1 & Median & Mean & Quartile 3 & St. Dev. \\
\hline FDA & Financial Debt/Total Assets \% & 3.57 & 18.81 & 21.51 & 34.91 & 18.77 \\
\hline DR & Debt Ratio \% & 57.57 & 73.98 & 69.33 & 84.70 & 19.68 \\
\hline DOE & Debt to Equity \% & 1.36 & 2.84 & 4.75 & 5.54 & 6.50 \\
\hline ROE & Return on Equity \% & 4.22 & 10.72 & 15.23 & 20.69 & 15.66 \\
\hline ROS & Return on Sales \% & 1.84 & 3.27 & 4.55 & 5.85 & 4.24 \\
\hline OPD & Operating profit / Total debt \% & 4.75 & 7.93 & 13.31 & 16.13 & 13.79 \\
\hline EOI & Ebitda on Investment \% & 6.03 & 9.05 & 11.83 & 14.46 & 9.08 \\
\hline ROI & Return on Investment \% & 4.03 & 6.49 & 9.25 & 11.44 & 8.41 \\
\hline ROA & Return on Assets \% & 3.66 & 5.71 & 7.58 & 9.70 & 5.88 \\
\hline
\end{tabular}

Source: Authors' estimations.

\section{Descriptive Analysis}

The correlation analysis reveals the trends and levels of interrelatedness between the two variables. The correlation matrix for the variables is reported in Table 2. The results show that debt is negatively correlated with profitability, while, in some cases, this negative effect becomes weak and unclear. Looking at the relationship between the indicators themselves, the results show that multicollinearity is not a problem in the implementation of analytical techniques.

Table 2. Pearson Correlation Matrix

\begin{tabular}{|l|c|c|c|}
\hline & FDA & DR & DOE \\
\hline ROE & -0.17575 & 0.08980 & 0.07793 \\
\hline ROS & -0.11054 & -0.44341 & -0.26119 \\
\hline OPD & -0.36295 & -0.68416 & -0.34169 \\
\hline EOI & -0.31104 & -0.44959 & -0.29015 \\
\hline ROI & -0.29098 & -0.41960 & -0.26526 \\
\hline ROA & -0.24154 & -0.39567 & -0.28058 \\
\hline
\end{tabular}

Source: Authors' estimations.

Analysing the correlation matrix, all the values appear to be inversely related, except two values assigned to the ROE index, showing an undefined relationship between indebtedness and ROE. This result could be attributed to the real nature of this variable, consisting of an economic element (net earnings) and an asset ratio in the denominator. Hence, in the case of inadequate corporate capitalization, the relation of "debt to equity", for example, will naturally be high as well as the relation of "revenue to equity", if the aforementioned low company net-worth is considered. This indicator produces values with different, ambiguous and contradictory interpretations, avoiding the relevance of ROE as a univocal signaller of business profitability (Muscettola 2015a).

Nevertheless, even the economic indicator resulting from the relation between operating profit and total debt, including total liabilities in the denominator, appears to be fully influenced; there is a self-evident link to the 
strong negative correlation with the DR variable, also including total liabilities in the denominator.

The indices under the names FDA and DOE seem to be interrelated at a somewhat lesser extent with financial variables in general and specifically, the ROS index, the one among profitability variables featuring both numerator and denominator pulled out of the income statement. Evidently, there exists evidence of a negative correlation gradient, even though this relationship appears to be less relevant.

In order to analyse the relationship between corporate debt and profitability, we use a simple trend-smoothing technique. Sorting the "debt to equity" index in ascending order, from the least to the most indebted firm, ("DOE"), we analyse the related "return on sales" index, ("ROS"), for each company using the "simple moving average" (SMA) technique. We use two of the most representative indices of corporate debt and profitability, to detect both econometrically and graphically the trend of the averages. Both indices are preferred for the similar trends they exhibit in terms of average values and variances, as illustrated in Table 1. Moreover, they both have a slight dispersion of the mean.

In statistics, a moving average is a theoretical concept for analysing data points, based on the creation of a series of means for different subsets of the full distribution. In other words, it is a simple method to "smoothen" the data.

Given the rightly skewed distribution of the DOE ratio in a fixed subset of 40 observations, the first element of the moving average is obtained by taking the average of the initial 40 observations of the ROS series. The next averages are taken from an equal number of data (40 observations). A moving average is a set of numbers, each of which is the average of the corresponding subset.

Figure 1 shows that as the DOE index value increases, as depicted in the right scale, the ROS moving averages gradually decrease.

Figure 1. Simple Moving Average for ROS when Debt Increases

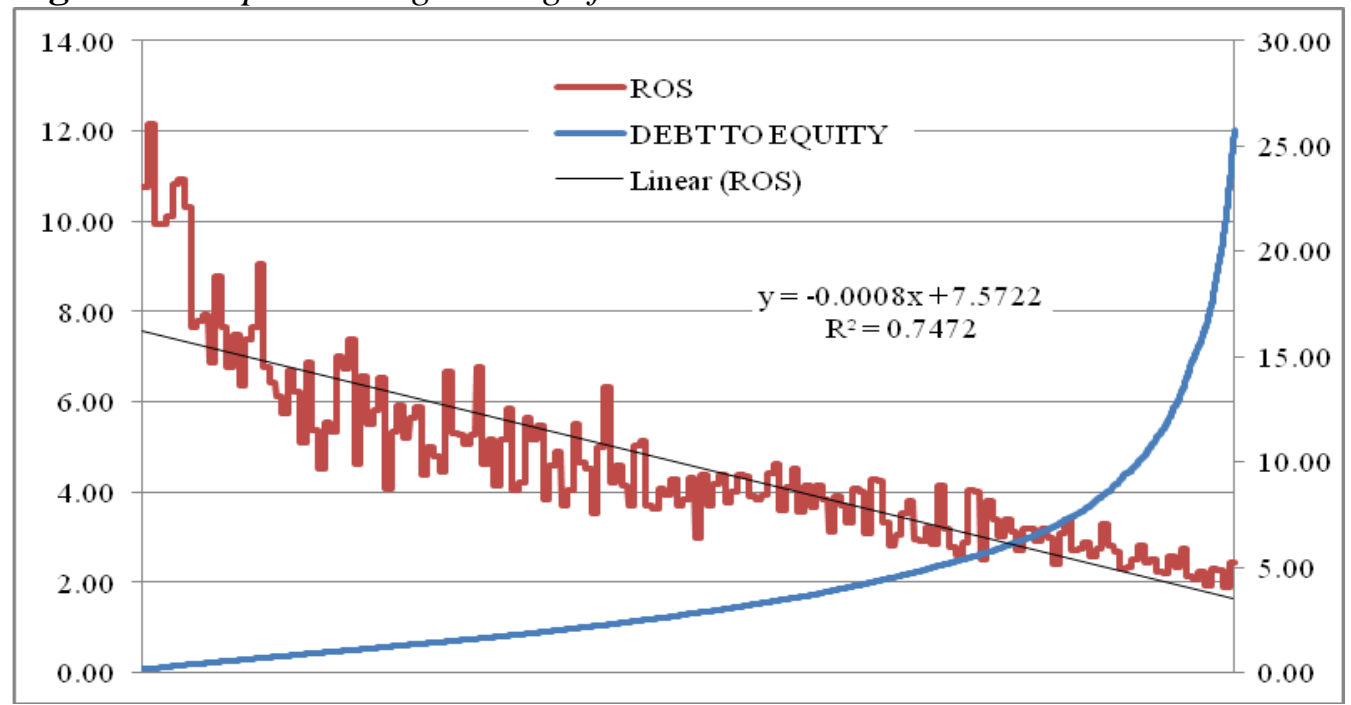

Source: Authors' estimations. 
The results of the linear regression further support the existence of a downward trend. The relationship between the $\mathrm{X}$ (DOE) and Y (ROS) variables is portrayed in the set of points on the coordinate plane $(\mathrm{X}, \mathrm{Y})$ forming an empirical line connecting $\mathrm{Y}$ to $\mathrm{X}$. The strong connection between the two indicators is also revealed by the R-squared statistic, taking a value higher than the ones obtained in previous studies, as well as by the correlations presented in Table 2 .

\section{Supply of Bank Credit in Italy}

Starting from some of the most iconic papers in the field, and, also, from the recent studies of Calza et al. (2003), Casolaro et al. (2006), Soresen et al. (2009) and Panetta and Signoretti (2010), it is possible to draw a representative map of "financial" Italy, distinguishing provinces on the base of the regional bank credit supply. In order to define the weight of the credit supply, we use an indicator made of the ratio between the total credit granted to firms in every province and the regional GDP (Gross Domestic Product). Based on this indicator the 101 Italian provinces are grouped in ten classes of the same size, scaled from class no 1, which represents the provinces with the lowest bank credit offer, up to class no 10, containing those areas with bank credit offer higher than the level of company production (Table 3 ).

Table 3. Provincial Classes Sorting by Bank Credit on Provincial GDP

\begin{tabular}{|c|c|c|}
\hline & \multicolumn{2}{|c|}{ Bank credit/GDP } \\
\hline Classes & From & To \\
\hline $\mathbf{1}$ & 0.29964 & 0.473505 \\
\hline $\mathbf{2}$ & 0.482741 & 0.562942 \\
\hline $\mathbf{3}$ & 0.564802 & 0.661278 \\
\hline $\mathbf{5}$ & 0.672306 & 0.735099 \\
\hline $\mathbf{6}$ & 0.736771 & 0.883147 \\
\hline $\mathbf{7}$ & 0.884844 & 1.060782 \\
\hline $\mathbf{8}$ & 1.065172 & 1.201761 \\
\hline $\mathbf{9}$ & 1.206378 & 1.335283 \\
\hline $\mathbf{1 0}$ & 1.387119 & 1.77538 \\
\hline
\end{tabular}

Source: Authors' estimations.

On the basis of this categorisation, the possible links between the bank credit market and the business capital structure are identified, presuming that, in certain zones with low credit offer, banks prefer to grant only firms featuring a major profitability, even though those companies ought to present the minimum need for financial support.

Afterwards, we juxtapose the output of the ten sub-samples built on the base of the bank credit offer to the results obtained from the whole sample. Then, we proceed to the correlations among the three debt indices and the six corporate profitability measures, separately analysing the ten aforementioned sub-samples. 
Table 4. Correlation Matrix Between Financial Debts on Assets (FDA) and Profitability Ratios Divided for Provincial Classes

\begin{tabular}{|c|c|c|c|c|c|c|}
\hline & ROE & ROS & OPD & EOI & ROI & ROA \\
\hline $\mathbf{1}$ & -0.22 & 0.03 & -0.21 & -0.24 & -0.22 & -0.17 \\
\hline $\mathbf{2}$ & -0.27 & 0.10 & -0.25 & -0.28 & -0.26 & -0.17 \\
\hline $\mathbf{3}$ & -0.11 & 0.04 & -0.33 & -0.25 & -0.21 & -0.16 \\
\hline $\mathbf{4}$ & -0.28 & -0.05 & -0.39 & -0.37 & -0.37 & -0.33 \\
\hline $\mathbf{5}$ & -0.11 & -0.11 & -0.34 & -0.32 & -0.26 & -0.19 \\
\hline $\mathbf{6}$ & -0.15 & -0.03 & -0.32 & -0.23 & -0.24 & -0.20 \\
\hline $\mathbf{7}$ & -0.16 & 0.01 & -0.27 & -0.28 & -0.24 & -0.14 \\
\hline $\mathbf{8}$ & -0.24 & -0.19 & -0.41 & -0.34 & -0.33 & -0.30 \\
\hline $\mathbf{9}$ & -0.15 & -0.23 & -0.44 & -0.36 & -0.33 & -0.30 \\
\hline $\mathbf{1 0}$ & -0.10 & -0.11 & -0.40 & -0.30 & -0.31 & -0.27 \\
\hline
\end{tabular}

Source: Authors' estimations.

Table 5. Correlation Matrix Between Debt on Equity (DOE) and Profitability Ratios Divided for Provincial Classes

\begin{tabular}{|c|c|c|c|c|c|c|}
\hline & ROE & ROS & OPD & EOI & ROI & ROA \\
\hline $\mathbf{1}$ & 0.07 & -0.07 & -0.18 & -0.18 & -0.12 & -0.11 \\
\hline $\mathbf{2}$ & 0.18 & -0.24 & -0.34 & -0.17 & -0.17 & -0.27 \\
\hline $\mathbf{3}$ & 0.13 & -0.31 & -0.34 & -0.29 & -0.28 & -0.28 \\
\hline $\mathbf{4}$ & 0.05 & -0.24 & -0.32 & -0.28 & -0.26 & -0.29 \\
\hline $\mathbf{5}$ & 0.03 & -0.25 & -0.30 & -0.29 & -0.24 & -0.24 \\
\hline $\mathbf{6}$ & -0.02 & -0.24 & -0.30 & -0.25 & -0.21 & -0.22 \\
\hline $\mathbf{7}$ & 0.18 & -0.21 & -0.36 & -0.25 & -0.24 & -0.24 \\
\hline $\mathbf{8}$ & 0.08 & -0.26 & -0.33 & -0.31 & -0.27 & -0.28 \\
\hline $\mathbf{9}$ & 0.06 & -0.32 & -0.42 & -0.34 & -0.34 & -0.35 \\
\hline $\mathbf{1 0}$ & 0.04 & -0.29 & -0.33 & -0.31 & -0.28 & -0.29 \\
\hline
\end{tabular}

Source: Authors' estimations.

Table 6. Correlation Matrix Between Debt Ratio (DR) and Profitability Ratios Divided for Provincial Classes

\begin{tabular}{|c|c|c|c|c|c|c|}
\hline & ROE & ROS & OPD & EOI & ROI & ROA \\
\hline $\mathbf{1}$ & 0.23 & -0.16 & -0.42 & -0.26 & -0.15 & -0.15 \\
\hline $\mathbf{2}$ & 0.12 & -0.32 & -0.66 & -0.28 & -0.28 & -0.36 \\
\hline $\mathbf{3}$ & 0.12 & -0.47 & -0.75 & -0.47 & -0.47 & -0.43 \\
\hline $\mathbf{4}$ & 0.04 & -0.48 & -0.68 & -0.46 & -0.45 & -0.50 \\
\hline $\mathbf{5}$ & 0.07 & -0.40 & -0.66 & -0.53 & -0.42 & -0.36 \\
\hline $\mathbf{6}$ & 0.09 & -0.42 & -0.53 & -0.26 & -0.21 & -0.22 \\
\hline $\mathbf{7}$ & 0.17 & -0.40 & -0.68 & -0.43 & -0.43 & -0.37 \\
\hline $\mathbf{8}$ & 0.03 & -0.43 & -0.64 & -0.44 & -0.41 & -0.37 \\
\hline $\mathbf{9}$ & 0.11 & -0.52 & -0.74 & -0.50 & -0.50 & -0.45 \\
\hline $\mathbf{1 0}$ & 0.15 & -0.41 & -0.68 & -0.47 & -0.41 & -0.35 \\
\hline
\end{tabular}

Source: Authors' estimations. 
Looking at the Tables 4, 5, and 6, it is evident that in the first classes, where a minor bank credit offer is supposed to be available to firms, the connection of indebtedness with profitability gets less evident to the companies. Even omitting the ROE index, being a quite negligible measure, the correlation appears quite scarce, even turning positive in the first three classes of credit offer in the correlation matrix of FDA and ROS.

Following this analysis, we repeat the graphic analysis of the moving averages between DOE and ROS, as we already did with the total sample, but this time focusing our analysis on each sub-sample within the ten territorial classes (Figures 2, 3, 4, 5, and 6).

Figure 2. Simple Moving Average for ROS when Debt Increases in Areas 1 and 2

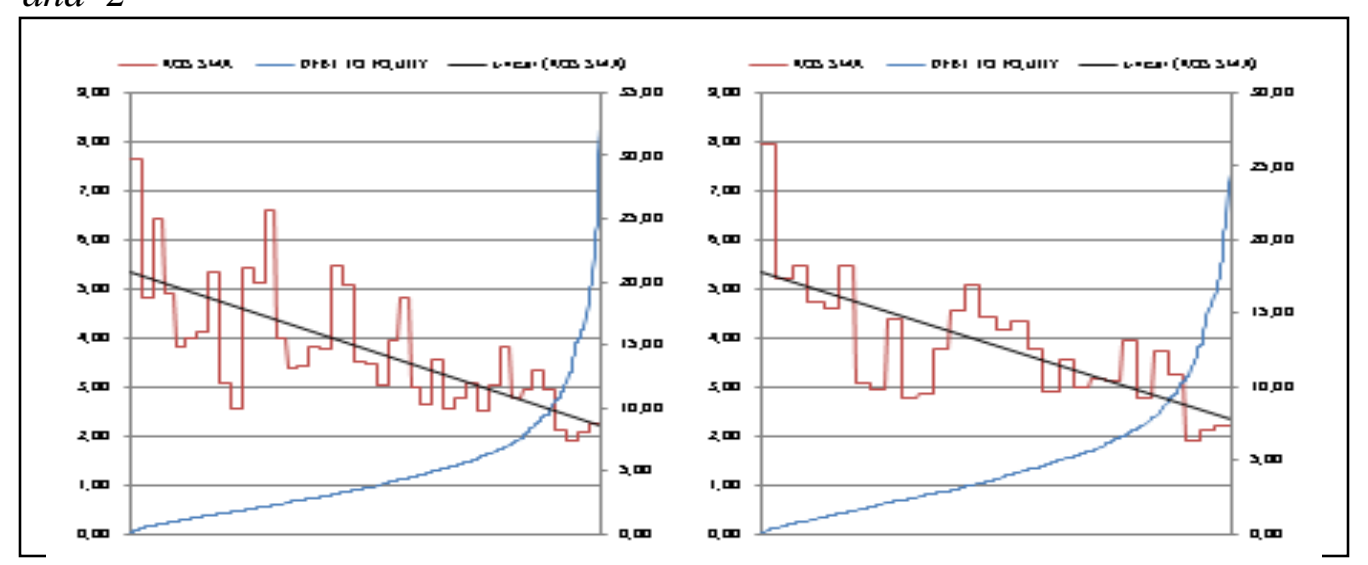

Source: Authors' estimations.

Figure 3. Simple Moving Average for ROS when Debt Increases in Areas 3 and 4

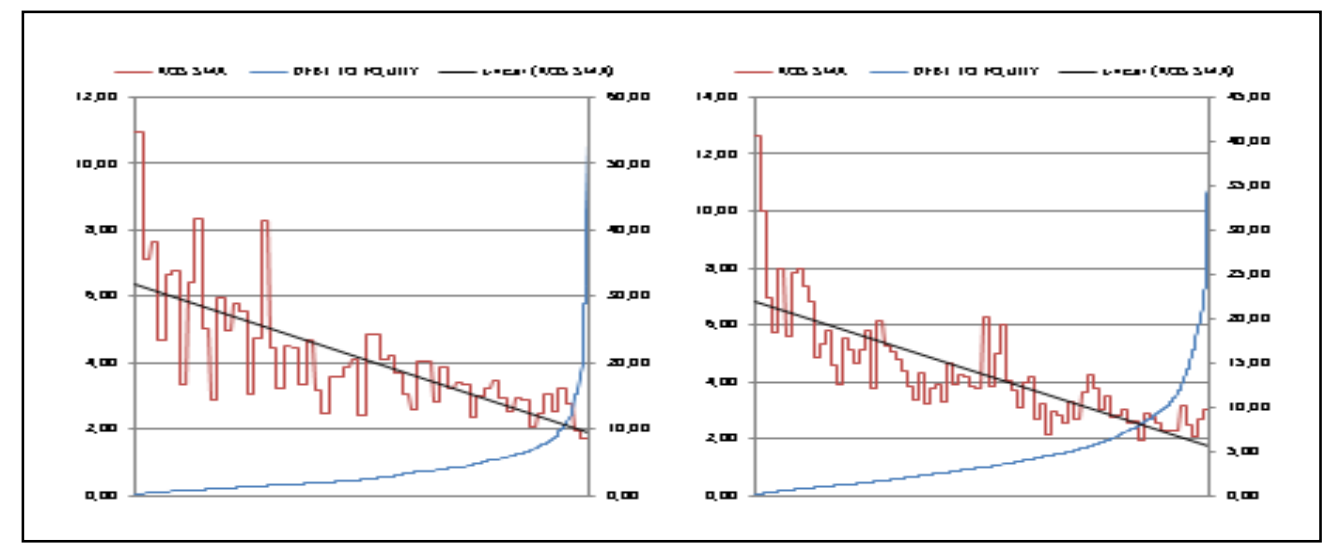

Source: Authors' estimations. 
Figure 4. Simple Moving Average for ROS when Debt Increases in Areas 5 and 6

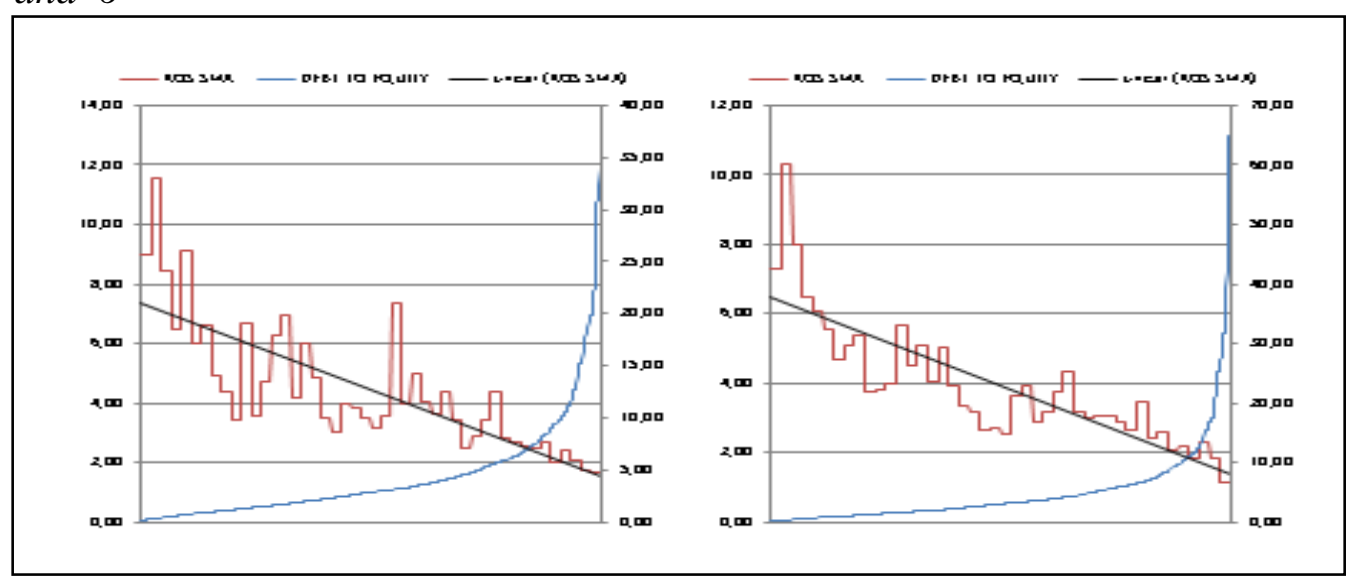

Source: Authors' estimations.

Figure 5. Simple Moving Average for ROS When Debt Increases in Areas 7 and 8

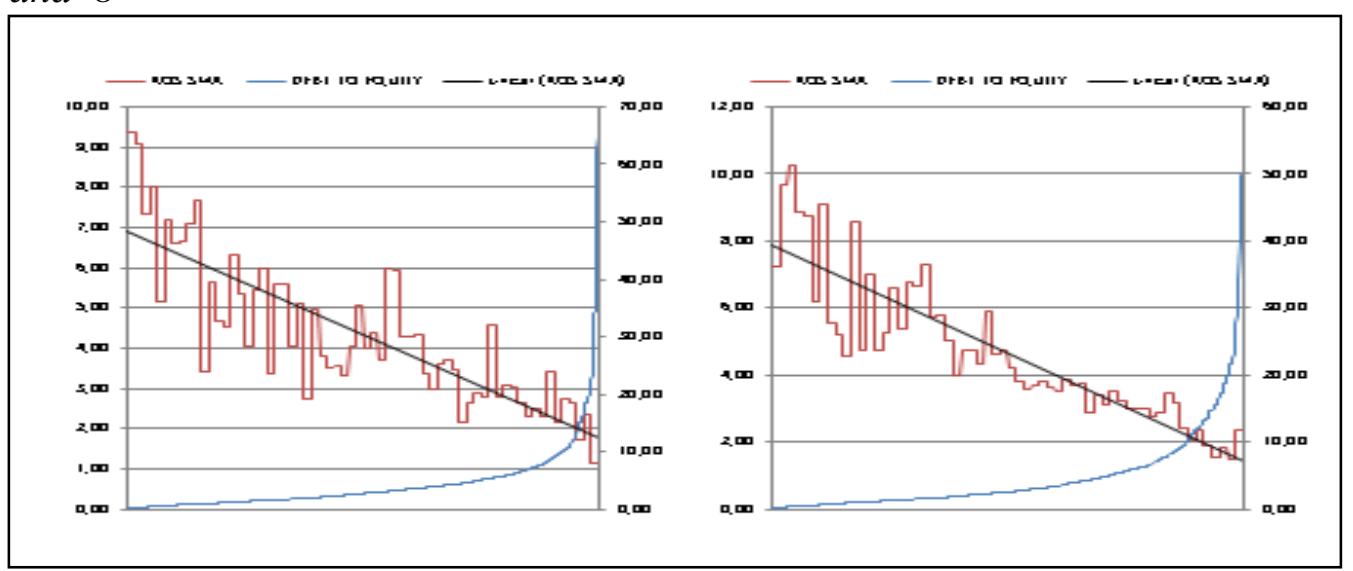

Source: Authors' estimations.

Figure 6. Simple Moving Average for ROS when Debt Increases in Areas 9 and 10

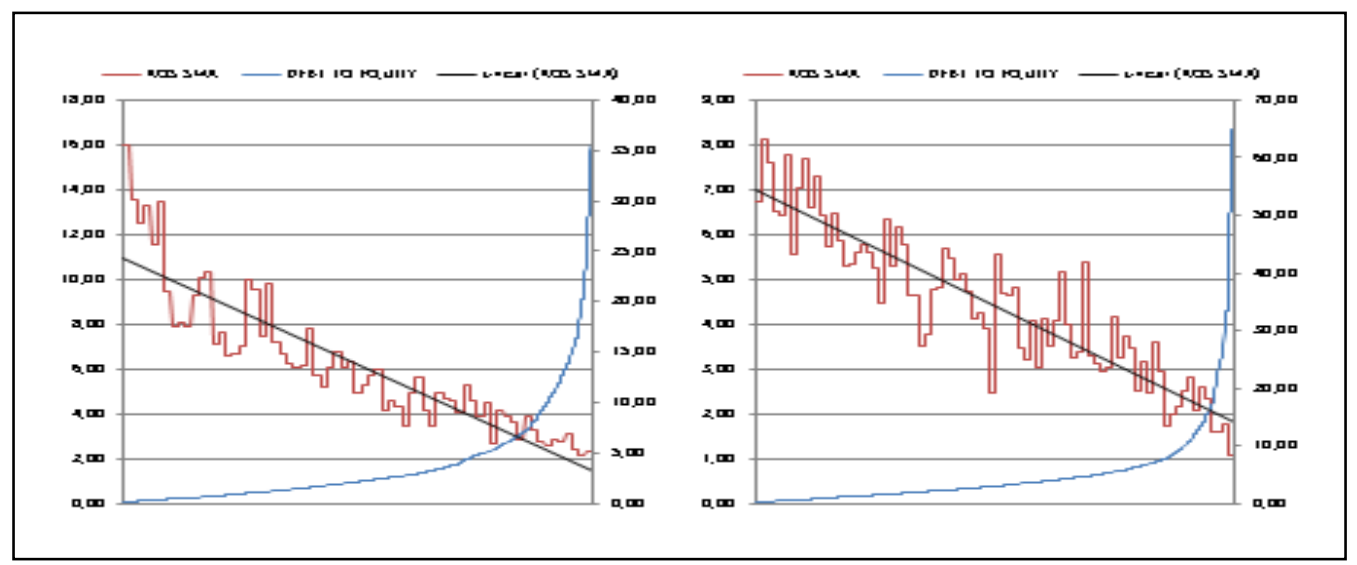

Source: Authors' estimations. 
Table 7 is even most relevant as it compares the $\mathrm{R}$ squared statistic ${ }^{1}$ of the ten sub-samples obtained in the moving averages analysis of ROS, as the DOE index increases. In order to avoid too long arrays, which might have distorted the linearity of the moving averages, we truncate the distributions of the first and last decile, thus, obtaining less inclined curves.

The most noteworthy outcome, indeed, is the trend followed by medium companies, keeping their debts low or being absolutely not indebted. The following table shows the ten R-squared statistics referring to each specific trend per specific territory.

Evidently, in territorial areas with a minor bank credit offer, the linear prediction model, defining corporate profitability, expressed in SMA, as a function of rising debt is less expressive. In other words, the linear trend found to exist between ROS and DOE is not in effect unlike in those areas with a higher credit offer, where, in spite of a major credit offer, firms with higher profitability logically opt for a lower grade of indebtedness.

Therefore, the starting hypothesis, according to which "if the firm grows in profitability, financial indebtedness should be reduced", is valid in territories with a larger bank credit offer; elsewhere, it is not so clear if a relationship of inverse proportionality exists.

Table 7. Regression Results by Territory

\begin{tabular}{|c|c|c|}
\hline Independent variable $(\mathbf{X})$ & Dependent variable (Y) & R-squared \\
\hline DOE - AREA 1 & ROS - AREA 1 & 0.230993 \\
\hline DOE - AREA 2 & ROS - AREA 2 & 0.157906 \\
\hline DOE - AREA 3 & ROS - AREA 3 & 0.341674 \\
\hline DOE - AREA 4 & ROS - AREA 4 & 0.527269 \\
\hline DOE - AREA 5 & ROS - AREA 5 & 0.394044 \\
\hline DOE - AREA 6 & ROS - AREA 6 & 0.545315 \\
\hline DOE - AREA 7 & ROS - AREA 7 & 0.468977 \\
\hline DOE - AREA 8 & ROS - AREA 8 & 0.552682 \\
\hline DOE - AREA 9 & ROS - AREA 9 & 0.591711 \\
\hline DOE - AREA 10 & ROS - AREA 10 & 0.612411 \\
\hline
\end{tabular}

Source: Authors' estimations.

\section{Conclusions}

These findings are consistent with that of Baum et al.'s (2007) on American industrial companies. Additionally, when we focus on geographical areas where the supply of bank credit is lower, debt appears not to have the same impact on the profitability of firms. As a future direction for research, it

\footnotetext{
${ }^{1} \mathrm{R}$ squared is a number that indicates how well data fit a statistical model. It is a statistic used in the context of statistical models whose main purpose is the testing of hypotheses, on the basis of other related information. It provides a measure of how well observed outcomes are replicated by the model, as the proportion of total variation of outcomes explained by the model.
} 
is proposed to take into account some considerations. First, it will be interesting to extend this analysis on manufacturing firms and, transversely, to take under consideration the specific components of corporate debt (financial debts, borrowings, long-term debts, bonds ...). Secondly, we would preferably incorporate in the model more detailed firm characteristics, such as macroeconomic factors, bargaining power of managers, terms and pricing of debts, ownership assembly of equity and location of the firm.

The present paper focuses on the relationship between financial structure and business profitability and the conclusion reached is that the theory of order of choice works only in certain areas, specifically where the credit offer is high. In these regions, the relationship between the two variables is negative; the firms, which are more profitable, are less indebted too. In the cases where there is lower credit intensity, due to reasons ascribable to demand and supply of funding, the correlation among the variables is weaker. In these areas, banks are more selective and they are more likely to provide funding to firms featuring higher ratings and a likely larger profitability. So, firms established in these zones have better access to bank financing, even though they do not need any help, as bank credit appears to be a secondary resource. This implies a further credit restriction for the firms with lower rankings, and so, the regional economic system is bound to eventually suffer all the negative consequences.

\section{References}

Abor J (2005) The effect of capital structure on profitability: An empirical analysis of listed firms in Ghana. The Journal of Risk Finance 6(5).

Abor J (2008) Determinants of the capital structure of Ghanaian Firms. African Economic Research Consortium. Research paper No. 176, Nairobi.

Accetturo A, Giunta Rossi S (2011) Le imprese italiane tra crisi e nuova globalizzazione (Italian companies between crisis and new globalization). Questioni di economia e finanza No. 86, January.

Albertazzi U, Marchetti D (2010) Credit supply, flight to quality and evergreening. Temi di discussione No. 756, April.

Amidu M (2007) Determinants of capital structure of banks in Ghana: an empirical approach. Baltic Journal of Management 2(1): 67-79.

Bakar SH (1973) Risk, leverage \& profitability: an industry analysis. Review of Economics \& Statistics 55: 503-7.

Baum CF, Schafer D, Talavera O (2007) The Effects of Short-Term Liabilities on Profitability: The Case of Germany, Money Macro and Finance (MMF) Research Group Conference 2006 61, Money Macro and Finance Research Group.

Bonaccorsi E, Sette E (2012) Bank Balance Sheets and the Transmission of Financial Shocks: Evidence from the 2007-2008 Crisis. Temi di discussione No. 848, January.

Calza A, Gartner C, Sousa J (2003) Modelling the Demand for Loans to the Private Sector in the Euro Area. Applied Economics 35(1): 107-117.

Cassar G, Holmes S (2003) Capital structure \& financing of SME's. Australian evidence. Journal of Accounting \& Finance 43(2): 1223-47. 
Casolaro L, Eramo G, Gambacorta L (2006) Un modello econometrico per il credito bancario alle imprese in Italia (An econometric model for bank lending to companies in Italy). Moneta e Credito, June.

Champion D (1999) Finance: The joy of leverage. Harvard Business Review 77(4): 19-22.

De Socio A (2010) La situazione economico-finanziaria delle imprese italiane nel confronto internazionale (The economic and financial situation of Italian companies in international comparison). Questioni di economia e finanza No. 66, April.

Di Giulio D (2009) Finanziamenti bancari al settore produttivo: Credit crunch o extracredito? (Bank loans to the productive sector: Credit crunch or extra-credit?). Temi di Economia e Finanza No. 1, ABI, Centro Studi e Ricerche, November.

Fama EF, French KR (1998) Taxes, financing decisions, \& firm value. Journal of Finance 53: 819-43.

Graham JR (2004) How big are the tax benefits of debt. Journal of Finance 55: 190141.

Hall GC, Hutchinson PJ, Michaels N (2004) Determinants of the capital structures of European SME's. Journal of Business Finance \& Accounting 31(5): 711-28.

Kester WC (1986) Capital \& ownership structure: a comparison of United States \& Japanese manufacturing companies. Asian Economic Journal 20(3): 275-302.

Leibenstien H (1966) Allocative Efficiency vs. X-Efficiency. American Economic Review 56: 392-415.

Muscettola M, Gallo M (2008) Analisi e gestione del rischio di credito (Analysis and risk management of credit). Il progetto Mayflower. FrancoAngeli Editore.

Muscettola M, Pietrovito F (2012) Le caratteristiche delle imprese insolventi. Il Rating tra impresa, banca e territorio (The characteristics of the insolvent company. The Rating between company, bank and territory). Rapporti di ricerca, 36. Sinergie Editore.

Muscettola M, Naccarato F (2013) Probability of default and probability of excellence, an inverse model of rating. one more tool to overcome the crisis: an empirical analysis. Business System Review 2(2).

Muscettola M (2013) Leverage Risk. The weight of borrower capital distinguishes the solvency of firms: an empirical analysis on a sample of 4,500 Italian SMEs. International Journal of Economics and Finance 5(12).

Muscettola M (2014a) Cash conversion cycle and firm's profitability. An empirical analysis on a sample of 4,226 manufacturing SMEs of Italy. International Journal of Business and Management 9(5).

Muscettola M (2014b) Structure of assets and capital structure. What are the relations with each other? An empirical analysis of a sample of Italy. European Journal of Business and Social Sciences 2(11): 55-69.

Muscettola M (2014c) Effects of Fixed Capital Investments in current economic downturn. International Journal of Management \& Information Technology 9(3).

Muscettola M (2014d) Probability of efficiency: Statistical implications that lead firms to achieve a minimal and sufficient ROI. Empirical evidence on a sample of 5,388 Italian SMEs. Journal of Management and Strategy 5(5).

Muscettola M (2015a) Predictive ability of accounting ratios for bankruptcy. Journal of Applied Finance \& Banking 5(1).

Muscettola M (2015b) Difficulties for small firms to invest in research prerogatives. An empirical analysis of a sample of Italian firms. Applied Economics 47(15).

Muscettola M (2015c) L'intensità della domanda e dell'offerta di credito bancario come fattore rilevante di classificazione delle imprese (The intensity of demand 
and supply of bank credit as a relevant factor for the classification of companies). Rivista Bancaria - Bancaria Minerva.

Nerlove M (1968) Factors affecting difference among rates of return on individuals common status. Review of Economics \& Statistics 50: 312-31.

Panetta F, Signoretti F (2010) Domanda e offerta di credito in Italia durante la crisi finanziaria (Demand and supply of credit in Italy during the financial crisis). Questioni di economia e finanza No. 63, April.

Petersen M, Rajan R (1994) The benefits of lending relationships: evidence from small business data. Journal of Finance 47: 3-37.

Rajan RG, Zingales L (1995) What do we know about capital structure? Some evidence from international data. Journal of Finance 50: 21-60.

Roden DM, Lewellen WG (1995) Corporate capital structure decisions: evidence from leveraged buyouts. Financial Management 24: 76-87.

Saleem Q, Rehman RU (2011) Impacts of Liquidity Ratios on Profitability. Interdisciplinary Journal of Research in Business 1(7): 95-98.

Sørensen K, Marqués Ibáñez CD, Rossi C (2009) Modelling loans to non-financial corporations in the euro area. Working Paper Series 989, European Central Bank.

Taub AJ (1975) Determinants of the firms capital structure. Review of Economics \& Statistics 57: 137-51.

Titman S, Wessels R (1988) The determinants of capital structure choice. Journal of Finance 43(1): 1-19. 
